\title{
THE BALKANS AS GEOPOLITICAL PERIPHERY OF EASTERN EUROPE - PAST IMPLICATIONS FOR AN UNCERTAIN FUTURE ${ }^{2}$
}

\author{
https://doi.org/10.18485/iipe_balkans_rssc.2020.ch5
}

\begin{abstract}
In the post-Cold War period, the Balkan Peninsula experienced the issue of "Balkanization" - fragmentation of once compact multiethnic political space - similar to the one it had already experienced in the $19^{\text {th }}$ and early $20^{\text {th }}$ century. Both historical instances of Balkanization countered wider European integrative trends of the time. A historical comparison between the first and the second Balkanization finds the cause for this "repeating" of history in an extraordinary geopolitical position of the peninsula as the periphery of geopolitically significant Eastern Europe. As a theoretical framework, Miller-Kagan's patterns of great powers' involvement in regional conflicts are used, alongside with geopolitical classic Halford Mackinder's concept of Eastern Europe. The main thesis is that due to the peripheral position of the Balkans within Eastern Europe, the great powers' influence in the region has been continuously limited instead of opting for integration like they did in Central-East Europe (a region of higher priority) they allowed local actors to balkanize their political space. However, the Balkans was just a pioneer of the first Balkanization - after World War I the process spread throughout Eastern Europe. Signs that the second Balkanization is also spreading - not only in Eastern Europe (with further fragmentation of the post-Soviet space) but also throughout the EU (with the rise of sovereignism due to the migrant crisis, as well as with regional separatism in several Western European countries) - are clearly visible. The conclusion is that in times of global uncertainty, explaining historical similarities could help in answering the challenges before they arise.
\end{abstract}

Keywords: Balkanization, the Balkans, great powers, geopolitics, Eastern Europe, Halford Mackinder.

\footnotetext{
${ }^{1}$ Research Fellow, Institute of International Politics and Economics, Belgrade, Serbia. E-mail: vtrapara@diplomacy.bg.ac.rs

${ }^{2}$ The paper presents findings of a study developed as a part of the research project "Serbia and challenges in international relations in 2020", financed by the Ministry of Education, Science, and Technological Development of the Republic of Serbia, and conducted by Institute of International Politics and Economics, Belgrade.
} 


\section{INTRODUCTION}

For more than a hundred years, the Balkans has been widely known as a "powder keg" of Europe. World War I erupted following the event that happened in the Balkans. The civil war in Balkan state Yugoslavia was the first event to deny that the "end of history" arrived with the end of the Cold War. It seemed that the early $20^{\text {th }}$ century history was repeated at its end in the Balkans. Yet, there is much more to this comparison because these two historic events - World War I and the Yugoslav civil war - were part of much wider processes, which as well included events that preceded and followed them. These processes - in this paper referred to as the first and the second Balkanization - show some striking similarities between each other. The theoretical goal of this paper is to analyze these similarities to establish the main factors that cause Balkanization and its spreading to other areas. The practical one is to derive lessons from history in order to formulate what is needed to reverse the current trend of Balkanization spreading. The rest of the paper is organized as follows. First, the definition of Balkanization is offered, two historical instances of Balkanization are described, and the main factors that cause it are identified. Second, the third and decisive factor - patterns of the great powers' influence in the Balkans - is further elaborated. Third, these patterns are explained by the geopolitical position of the Balkans as the periphery of Eastern Europe. Fourth, the current spread of the second Balkanization and possibilities of its reversing are considered. Finally, the main theoretical and practical arguments are summarized in the Conclusion.

\section{THE TWO BALKANIZATIONS}

To "balkanize" something means "to break up (a region, a group, etc.) into smaller and often hostile units" (Balkanize, 2019). In the context of this paper, "Balkanization" refers to "the violent fragmentation of larger states into smaller, mutually hostile and barely viable units" (Perica, 2019, p. 47). Or in less harsh and pejorative words, it is simply the fragmentation of a politically compact multiethnic space into several smaller would-be nationstates. The term originated at the end of World War I to describe the formation of new nation-states throughout Eastern Europe on the territories of former empires (Andersen and Pinos, 2015, p. 25). This process was named after the Balkan Peninsula, which had already experienced the division into several small states with troublesome mutual relations during the period between the Napoleonic Wars and World War I. The 
establishment, expansion, and mutual struggles for power and territories of Greece, Serbia, Montenegro, Romania, Bulgaria, and Albania on most of the peninsula that was once firmly in the hands of the Ottoman Empire, ran counter to a wider European trend of the time. As a result of divisions of Poland at the end of $18^{\text {th }}$ and German unification in the second half of the $19^{\text {th }}$ century, on the eve of World War I in the rest of Eastern Europe, there were no nation-states other than three empires and the great powers: Germany, Russia, and Austria-Hungary. The neighbouring Apennine Peninsula was no different - several small states there united into a single Italy. The Balkans was the only place in Europe (actually, after the decolonization of Latin America was finished, in the world) where new small states appeared in large quantities. ${ }^{3}$

Thus, it was not a surprise that the Balkans was used as a word for coining a new term that would denote fragmentations of multiethnic political spaces that followed - first in the rest of Eastern Europe and the Middle East after the World War I, and later with the decolonization in Asia and Africa after World War II (Andersen and Pinos, 2015, p. 25). What begs for an explanation is why was exactly the Balkans the place in which Balkanization started, even when the overall international trend was quite the opposite? The question gained even greater significance after the Balkanization was back to the Balkans in the post-Cold War period, with the dissolution of Yugoslavia (Andersen and Pinos, 2015, p. 25; Simić, 2013, p. 114). Once again, it was opposite to wider European trend of integration with the formation of the EU, yet it now seems to be an introduction to new fragmentations throughout Europe in the $21^{\text {st }}$ century - first in post-Soviet space, then with increased regional separatism in Western Europe, and finally with the rise of sovereignism in some EU members due to the migrant crisis.

Three factors can be identified that enabled what we would call "the first Balkanization" in the $19^{\text {th }}$ and early $20^{\text {th }}$ century. Two of them are connected to the character of the Ottoman Empire: its relative weakness compared to European great powers and its peculiar internal arrangement. The third one is about patterns of great powers' influence in the region. All three factors also contributed to "the second Balkanization" at the end of the $20^{\text {th }}$ century - one just needs to replace the Ottoman Empire with SFR Yugoslavia. The first and the second factor are easy to consider, even by common sense. In the $19^{\text {th }}$ century, Ottoman Turkey was a former great power, an empire in

\footnotetext{
${ }^{3}$ The only other European examples, but in "smaller quantities", were Belgium (1839) and Norway (1905).
} 
decline. Unlike other great European powers who were the main subjects in international politics, bent on aggrandizing their own territories and colonial possessions, Turkey was an object in a vain struggle to survive. So, it was not surprising that new states could emerge only in its territory since the rest of the European continent had already been carved up by far stronger and more stable powers who supported Balkan national liberation movements at one time or another. Their formulation of the "Eastern question" was a clear sign of the Ottoman Empire's weakening (Arlsan, 2019, p. 408). Similarly, SFR Yugoslavia could have been an influential international actor only due to its geopolitical position between the spheres of influence of two superpowers that balanced each other. Yet, it was a small and weak state on both world and European scale, and would not stand a chance against any of the superpowers alone.

When it comes to the second factor, Ottoman Turkey organized its subject peoples by a model of millets, religious communities that had some degree of autonomy, which was not territorial (Hagen, 1999, pp. 52-53; Mylonas, 2019, pp. 866-868). When these religious divisions became the basis for nation-building, their non-territorial nature and the fact that ethnic and religious groups were territorially mixed produced two outcomes: too much particularism in matters of territory and identity, which prevented the construction of one or two unified Balkan state(s); bitter clashes between would-be nation-states in the Balkans over territories and identities. SFR Yugoslavia also had a complex internal arrangement, with borders between the federal units that cut across dispersed and mixed ethnic and religious groups, which led these groups to conflicts over the interpretation of national borders and identities after the former multi-ethnic common state collapsed (Perica, 2019, p. 42).

\section{THE BALKANS AND THE GREAT POWERS}

Although the two mentioned factors explain why territorial spaces of the Ottoman Empire and SFR Yugoslavia were more prone to political fragmentation to small and mutually hostile units compared to the rest of Europe, they still do not explain why the two Balkanizations actually happened. As the main actors on the European stage, the great powers still had the last word over territorial outcomes of Ottoman Turkey and Yugoslavia's collapse - why did they allowed Balkanization in both historical instances, instead of opting to create a lesser number of greater states (or even a single one) in the region, or (in the case of the first 
Balkanization, when such practice was still allowed by international law) to annex parts of the region themselves, like they did in the rest of Eastern Europe? This leads us to consider the third factor, which would also explain why Balkanization in both instances expanded (or would yet expand) to European regions that do not share the presence of the first two factors to an equal extent - patterns of great powers' influence in the Balkans.

To this end, the model of great powers' (non)involvement in regional conflicts, developed by Benjamin Miller and Korina Kagan, is a useful tool. Miller and Kagan recognize four patterns of great powers involvement in regional conflicts: competition, cooperation, disengagement, and dominance (1997, pp. 57-58). These patterns are conditioned by the great powers' capabilities (overall and those of power projection to the region in question) and interests. Competition and cooperation are more likely in the case of equal capabilities and interests, while disengagement and dominance occur when asymmetry is present (Miller and Kagan, 1997, pp. 61-64). Higher great powers' competition leads to higher small states' "positive" autonomy (ability to manipulate the great powers), which causes intensified local conflicts. Great powers' cooperation reduces the degree of small states' autonomy and leads to conflict mitigation. When the great powers disengage from a region, the degree of small states' autonomy increases and conflicts remain uninterrupted; when only some of the great powers disengage, the remaining one can establish hegemony. Dominance means very low autonomy of regional small states and highly effective conflict management, even more than in the case of cooperation; the price is the liberty of small states, especially if hegemon is not democratic (Miller and Kagan, 1997, pp. 59-61).

Miller and Kagan claim that the creation of several newly independent states in the Balkans between the congresses of Vienna and Berlin was the result of great powers' cooperation in conflict management on the peninsula (1997, pp. 66-69). Between 1880 and 1914 there was competition in the region between Austria and Russia, which increased Balkan states' autonomy and their capability to manipulate the great powers for their own ends, resulting in their further territorial expansion at the expense of Turkey, conflicts between Bulgaria and its neighbours, and creation of independent Albania (Miller and Kagan, 1997, pp. 69-71). Finally, according to these two authors, the war in former Yugoslavia was the result of Soviet disengagement and limited Western engagement in the region, until the United States established its dominance (Miller and Kagan, 1997, pp. 76-78). Miller and Kagan published their article in 1997, so they could not include the 
continuation of Balkanization in former Yugoslavia even under the U.S. dominance: with the independence of Montenegro and self-proclaimed independence of Kosovo. What catches the eye here is that under all four Miller-Kagan's patterns of great powers' involvement in the Balkans regardless of whether the regional conflicts were managed, left uninterrupted, or intensified - the repeating feature was Balkanization, in the sense of political fragmentation of the region into small and mutually hostile units.

This can be explained with what lies in the essence of Miller-Kagan's patterns of great powers' involvement in regional conflicts - actual capabilities and interests of these powers. They say all great powers save for Prussia/Germany had high interest in the Balkans between 1815 and 1914, which at first led to their cooperation, and later to competition (p. 66). Nevertheless, they do not say that exactly the least interested power Germany, whose Chancellor Bismarck said that "the whole of the Balkans is not worth the bones of a single Pomeranian grenadier" - in the role of the host of the Congress of Berlin, was a decisive broker of balkanizing solution for the Balkans (Simić, 2013, p. 117). France has never been deeply interested in the Balkan region (Napoleon III instrumentally used its issues to undermine the Vienna system). Austria's priorities got diverted to the Balkans only after its defeat in the war against Prussia 1866, lying in German Middle Europe before that. Russia and Britain's interests for most of the peninsula were instrumental as they clashed over the control of Constantinople and the Straits. British first tried to prevent the collapse of Turkey, but "lost faith in the ability of the 'sick man of Europe' to go on living and resigned themselves to the empire's partition" (Hagen, 1999, p. 53). Russia settled with Berlin's annulment of the San-Stefano Treaty too easily. Austria and Russia's interests in the region did increase from 1880 and 1914, eventually leading them to start World War I, but before that neither had enough capability to decisively influence Balkan matters; this is what Miller and Kagan recognize when saying that the Bucharest treaty of 1913 was concluded between the Balkan states themselves, and not submitted to the approval of the great powers (1997, p. 71). They also confirm that Yugoslavia collapsed as the result of the great powers' disengagement due to their low interests (the United States) and capabilities (the European Union), yet warned that U.S. interest in the Balkans remained low even after achieving dominance (1997, p. 79). Therefore, they could easily understand why the U.S. subsequently settled with further Balkanization as the simplest solution for local conflicts, rather than engaging in a more difficult task of regional integration. 


\section{THE BALKANS IN MACKINDER'S EASTERN EUROPE}

We can conclude that both Balkanizations were not products of too much influence of the great powers in the region - in case of which some of them would have either annexed or integrated parts of the Balkans under their own spheres of influence - but of their limited engagement due to their insufficient interests and/or capabilities. This was quite opposite to how the great powers behaved during the same periods in some other strategically more important areas, especially in the rest of Eastern Europe. Having in mind that the Balkans is also a part of Eastern Europe, to explain this contradiction we must observe an extraordinary geopolitical position of the peninsula as the peripheral part of vast East-European space. The notion of geopolitical East-West European divide is well-developed among scholars, but nowhere as convincingly as it is in the works of one of the classics of geopolitics, Sir Halford Mackinder.

Mackinder defined Eastern Europe as a combination of the Baltic and the Black Sea water basins, which is a natural extension of Eurasian Heartland, a vast area that covers continental waters' and the Arctic Ocean basins (Mackinder, 1919, pp. 130, 134-135, 148). The most famous Mackinder's quote is his syllogism: "Who rules East Europe commands the Heartland; who rules the Heartland commands the World-Island; ; who rules the World-Island commands the World" (Mackinder, 1919, p. 186). Therefore, Eastern Europe is a key concept in Mackinder's geopolitics, and a stepping stone towards global hegemony (Trapara, 2014, pp. 31-32). According to this logic, the main reason why no great power ever succeeded in establishing such hegemony is the fact that Eastern Europe never entirely fell under the control of a single power. Closest to achieving command over Eastern Europe in its entirety came Nazi Germany (during its offensive on the Eastern Front in World War II, which ultimately failed), Soviet Union (during the Cold War, but it was successfully contained before reaching western and southern borders of Eastern Europe), and the post-Cold War United States (whose geopolitical march to the East reached its peak and stalled with events in Ukraine in 2014). Given that a large portion of the Balkan Peninsula (which is also valid for former Yugoslavia) belongs to the Black Sea basin, we can consider it a part of Mackinder's East Europe, which means that the region should be of great geopolitical value for the great powers.

\footnotetext{
${ }^{4}$ Eurasia.
} 
However, the Balkans is more of an "appendix" to Eastern Europe than its first-class part; most of the great power history actually happened to the North and the East of it - in what is the rest of Eastern Europe, which we would call Central-Eastern Europe (CEE). This was an area in which the great powers - especially those closest to it, like Germany and Russia - could not afford to take chances, and needed to have a firm control over at least some portion of it. In the Balkans, they could afford gambling and neglect from time to time. In this sense, in the post-Cold War period they could even make a difference between specific parts of the Balkans - for example, Eastern half of the peninsula (Romania and Bulgaria) has much greater significance for U.S. geopolitical march to the East compared to what is now called the Western Balkans.

However, during the $19^{\text {th }}$ and at the beginning of the $20^{\text {th }}$ century, too much gambling and neglect in the peripheral, yet geopolitically still significant Balkans, brought great powers to a disastrous World War I in the end. In its aftermath, the first Balkanization spread to Central-Eastern Europe, mostly due to temporary disengagement of defeated Germany and revolutionary Russia (Miller and Kagan, 1997, p. 72). Hostilities between status quo and revisionist states in this region and the Balkans, in combination with unresolved border issues, would eventually lead to even more horrible World War II, during which Nazi Germany managed to establish temporary dominance over the regions and redraw its map in due process (Miller and Kagan, 1997, pp. 73-75). Another German defeat gave CEE and parts of the Balkans another master - the Soviet Union, which froze disputes over (some renewed, some newly established) borders, while Balkanization continued to spread elsewhere - in the shape of decolonization of Asia and Africa (Miller and Kagan, 1997, pp. 75-76). It is important to underline that neither Nazi Germany nor the Soviet Union was interested in the Balkans even close to how much they valued CEE.

It would be the same with the United States in the aftermath of the Cold War regarding Yugoslavia, in which Washington's low initial interest in combination with Russia's disengagement and European powers' lack of capabilities would produce the second Balkanization (Miller and Kagan, 1997, pp. 76-77). It appeared too easy to take another gamble in the Balkans, allowing Yugoslav federation to simply fall apart, yet much more difficult to defend the idea of federal units taking its place as newly established states with the existing non-ethnic borders. Of course, such mess was not allowed in a far more valued CEE (Romania and Bulgaria added), where conflicts were prevented and borders remained firm (with an insignificant exception 
of "velvet divorce" between the Czech Republic and Slovakia), while the whole region was set on a successful path to European integration. Even after engaging more robustly in ending the Yugoslav wars that were inevitable as the result of its initial behaviour, the U.S. would pursue much disinterested regional dominance way into the $21^{\text {st }}$ century, not bothering to resolve a single open issue between and within troubled Balkan states, while only rhetorically supporting their EU perspective, which still remains a far-away vision for most of the Western Balkans. It is yet to be seen how the appearance of a new great power in CEE and the Balkans - China under the "17+1" initiative will affect political stability in both regions.

\section{THE CURRENT SPREAD OF BALKANIZATION}

Yet, the fact that the Balkans (at least former Yugoslav space) remains a "powder keg" is not the most worrisome consequence of another great powers' neglect and gamble in this region. The main potential problem for Europe and the world is that 20 years into the $21^{\text {st }}$ century there are visible signs that - like it was the case with the first Balkanization a hundred years ago - the second Balkanization is also spreading to other areas, due to renewed conflicts and power redistribution between the great powers. And it is quite clear that everything once again has started in the Balkans. Western unilateral handling of the Kosovo crisis in 1998/1999, including NATO aggression against Yugoslavia, triggered Russia's orientation towards more assertive foreign policy. Facing subsequent NATO enlargement to the East, Russia would opt for the further Balkanization of post-Soviet space to prevent some of its neighbours' NATO membership. In 2008, after a brief war with Georgia, Moscow recognized the independence of South Ossetia and Abkhazia, and in 2014 responded to a pro-Western coup in Kiev by taking Crimea from Ukraine and supporting the creation of the Donetsk and Lugansk People's Republics on its territory. On both occasions, a "Kosovo precedent" was invoked by the Kremlin as a (quasi)legal justification for territorial changes (Trapara, 2018, pp. 41, 50).

The Middle East was the region that suffered even more from Western powers' unwillingness to act on the lessons learned in the Balkans. Unlike the mishandling of the Kosovo issue, the United States had a positive achievement in Bosnia and Herzegovina with the Dayton Accords, which stopped the war and laid the foundation for peaceful and functional relations between three Bosnian peoples (Trapara, 2016, pp. 57-58). Yet, the U.S. has been systematically working against this arrangement in the 
decades that followed, not even thinking of applying it elsewhere. Afghanistan, Iraq, Libya, Yemen and Syria (where Russia also got involved) ended up balkanized within themselves, with no Dayton for any of them in the sight. This triggered massive waves of refugees and economic migrants from these countries towards Europe, which caused what is now called the migrant crisis. This process recently affected intra-EU relations, with some members (especially those of CEE) "re-sovereignizing" themselves to avoid the influx of migrants, ignoring Brussels's quota system, even building physical barriers (like Hungary's fences on its southern border) against migrants' entry. This is a clear example of the second Balkanization spreading to the EU, but it is not the only one. The issues of political boundaries and territoriality, which 20-30 years ago seemed to remain reserved only for the Balkans, now seem to be fully back to the EU itself. Brexit, separatisms in Scotland and Catalonia, British-Spanish clash over Gibraltar - together make a threatening trend of a new political fragmentation throughout Europe (Andersen and Pinos, 2015, pp. 25-26; Gozubenli and Tekeshanoska, 2018, pp. 6-7). In 2014, even Pope Francis had to warn Western states, who had faced regional separatism, to do what they can to avoid "the tragedy of Balkanization" (Perica, 2019, p. 49).

Fortunately, this trend is not inevitable and can be reversed. History of the first Balkanization teaches us what should be done and what mistakes should not be repeated before it is too late. It is important because Balkanization "keeps ethnic conflicts in check, but it does not solve them" (Andersen and Pinos, 2015, p. 37). To stop the second European and global wave of Balkanization, one should go back to its roots - to the Balkans. The great powers (especially those in the West) should first admit that they acted irresponsibly and made some mistakes with their past policies in the region, and then change these policies in order to do their best to correct the mistakes. Of course, this should be done cooperatively - the U.S, the EU (and its most powerful members), Russia and China (as a new great power whose influence in the region is on the rise) should take responsibility and work together with local actors to find solutions for the open regional issues which would stabilize the region, and present this success as an example that could be applied in other areas that suffer from Balkanization. Instead of undermining the Dayton Accords and insisting on unconditional recognition of Kosovo independence, the U.S. and its allies should uphold the current constitutional arrangement for Bosnia as the only possible model which keeps this country together, while allowing for a more creative compromise solution to the status of Kosovo. If successful, both outcomes could then be, of course, taking into account local circumstances and 
working with local actors, used as a model to resolve conflicts and stop Balkanization in other places - from the Middle East, through the postSoviet space, to the EU itself.

\section{CONCLUSION}

We live in the age of great uncertainty. What yesterday was taken for granted tomorrow can be put into question. International Relations, as such, like all social sciences, are an uncertain scientific discipline in a perpetual struggle to explain the complex and changing international environment and try to predict the outcomes. Yet, history is a safe haven for IR researches, for if the present and the future are not certain, the past is - at least that part of it which is not contested. Therefore, it is not surprising that all major IR theories are formulated and tested on historic events and processes. Although we can never be sure about what is going on in the world, let alone what will happen, we can always observe some trends and search for similar ones in history to see what outcomes they produced, and under which conditions. It is obvious that the spreading of Balkanization is a trend of the day, for the conditions that caused its previous "edition" to spread are present once again. Yet, it is still a nascent challenge that can be answered and reversed. In this paper, it was argued that the great powers' gambling and neglecting behaviour in a peripheral part of a key geopolitical region of Eastern Europe was a primary condition of the first Balkanization and its later spreading throughout Europe and the world. Such behaviour was present, and it still is, in the second Balkanization, too. Therefore, going back to the roots and sealing off Balkan Pandora's box, should be viewed as a necessary condition for introducing some degree of order to uncertain global relations.

\section{REFERENCES}

Andersen, D. J. \& Pinos, J. C. (2015). Balkanization Revisited: Territorial Lessons from the Former Yugoslavia, in: Boundaries Revisited (pp. 25-40). Berlin, Logos Verlag.

Arlsan, M. (2019). Violence as a Means of Nation-Building: The Case of the Balkans (1890-1913), Journal of Muslim Minority Affairs, 39(3), pp. 395-410.

Balkanize. (2019, December 1), retrieved from https://www.merriamwebster.com/dictionary/balkanize. Accessed 11 December 2019. 
Gozubenli, A. S. \& Tekeshanoska, N. (2018). Europeanization of the Balkans vs. Balkanization of Europe: A Vision Limited by Realities, UBT International Conference, (390).

Hagen, W. W. (1999). The Balkans' Lethal Nationalisms, Foreign Affairs, 78(4), pp. 52-64.

Mackinder, H. J. (1919). Democratic Ideas and Reality: A Study in the Politics of Reconstruction. New York, Henry Holt and Company.

Miller B. \& Kagan, K. (1997). The Great Powers and Regional Conflicts: Eastern Europe and the Balkans from the Post-Napoleonic Era to the Post-Cold War Era, International Studies Quarterly, 41(1), pp. 51-85.

Mylonas, H. (2019). Nation-building policies in the Balkans: an Ottoman or a manufactured legacy?, Nations and Nationalism, 25(3), pp. 866-887.

Perica, V. (2019). Hundred Years Since Yugoslavia's Birth: Lesson on Nationalism, Balkanization, and Religion in Europe's Periphery, Occasional Papers on Religion in Eastern Europe, 39(1(3)), pp. 40-50.

Simić, P. (2013). Balkans and Balkanisation: Western Perceptions of the Balkans in the Carnegie Commission's Reports on the Balkan Wars from 1914 to 1996, Perceptions: Journal of International Affairs, 18(2), pp. 113-134.

Trapara, V. (2014). Savremeni značaj Makinderovog koncepta Istočne Evrope: slučaj ukrajinske krize [Contemporary Significance of Mackinder's East Europe Concept: The Case of the Ukrainian Crisis], Međunarodna politika [International Politics], 65(1155-1156), pp. 26-43.

Trapara, V. (2016). Višedimenzionalni istorijski značaj Dejtonskog sporazuma [Multi-dimensional historical significance of the Dayton Accords], in: Stevan Rapaić, Tijana Kecmanović \& Aleksandar Vranješ (Eds.), Dejtonski sporazum - dve decenije mira i pouke za svet [The Dayton Accords - Two Decades of Peace and Lessons for the World] (pp. 53-62). Belgrade, Representative Office of Republika Srpska in Serbia, Banja Luka, Faculty of Political Sciences, Belgrade, Institute of International Politics and Economics.

Trapara, V. (2018). 'Upotrebljivost' sile za ostvarivanje spoljnopolitičkih ciljeva u 21. veku: ruske intervencije u Gruziji (2008) i na Krimu (2014) ['Usefulness' of Force for Achieving Foreign Policy Goals in the 21 ${ }^{\text {st }}$ Century: Russia's Interventions in Georgia (2008) and Crimea (2014)], in: Žaklina Novičić (Ed.), Upotreba sile u medunarodnim odnosima [Use of Force in International Relations] (pp. 34-55). Belgrade, Institute of International Politics and Economics. 